\title{
Contribution to the understanding of the cycle of the protozoan parasite Marteilia refringens
}

\author{
I. ARZUL ${ }^{1}$, B. CHOLLET ${ }^{1}$, S. BOYER ${ }^{2}$, D. BONNET ${ }^{2}$, J. GAILLARD $^{1}$, Y. BALDI $^{3}$, \\ M. ROBERT ${ }^{1}$, J. P. JOLY ${ }^{1}$, C. GARCIA ${ }^{1}$ and M. BOUCHOUCHA ${ }^{4}$ \\ ${ }^{1}$ IFREMER SG2M-LGPMM, Laboratory of Genetics and Pathology of Marine Molluscs, 17390 La Tremblade, France \\ ${ }^{2}$ Laboratoire EcoSym, UMR5119, Université Montpellier 2, CC 093, Place Eugène Bataillon, 34095 Montpellier \\ Cedex 05, France \\ ${ }^{3}$ IFREMER Laboratory Environment and Resource Provence Azur Corse, 20600 Bastia, France \\ ${ }^{4}$ IFREMER Laboratory Environment and Resource Provence Azur Corse, 83507 La Seyne/Mer Cedex, France
}

(Received 3 Fune 2013; revised 3 Fuly and 16 Fuly 2013; accepted 21 Fuly 2013; first published online 11 October 2013)

\begin{abstract}
SUMMARY
The paramyxean parasite Marteilia refringens infects several bivalve species including European flat oysters Ostrea edulis and Mediterranean mussels Mytilus galloprovincialis. Sequence polymorphism allowed definition of three parasite types 'M', 'O' and 'C' preferably detected in oysters, mussels and cockles respectively. Transmission of the infection from infected bivalves to copepods Paracartia grani could be experimentally achieved but assays from copepods to bivalves failed. In order to contribute to the elucidation of the $M$. refringens life cycle, the dynamics of the infection was investigated in $O$. edulis, M. galloprovincialis and zooplankton over one year in Diana lagoon, Corsica (France). Flat oysters appeared non-infected while mussels were infected part of the year, showing highest prevalence in summertime. The parasite was detected by PCR in zooplankton particularly after the peak of prevalence in mussels. Several zooplanktonic groups including copepods, Cladocera, Appendicularia, Chaetognatha and Polychaeta appeared PCR positive. However, only the copepod species Paracartia latisetosa showed positive signal by in situ hybridization. Small parasite cells were observed in gonadal tissues of female copepods demonstrating for the first time that a copepod species other than $P$. grani can be infected with $M$. refringens. Molecular characterization of the parasite infecting mussels and zooplankton allowed the distinguishing of three Marteilia types in the lagoon.
\end{abstract}

Key words: bivalves, copepods, Marteilia refringens, Paracartia latisetosa, parasite life cycle, zooplankton.

\section{INTRODUCTION}

In France, aquaculture is mainly based on oyster production including production of Pacific cupped oyster, Crassostrea gigas, and in a lesser concern of flat oyster, Ostrea edulis. This last species is native from Europe where it occurs along the western European coast, the Mediterranean Sea and into the Black Sea. It is presently in the OSPAR (Oslo and Paris Conventions for the protection of the marine environment of the North-East Atlantic) list of threatened and/or declining species and habitats (OSPAR agreement, 2008-6) notably because it has suffered from two protozoan diseases, marteiliosis due to Marteilia refringens and bonamiosis due to Bonamia ostreae (Meuriot and Grizel, 1984; Goulletquer and Héral, 1997). Considering their impact on flat oyster populations, these two diseases have been included in the list of notifiable diseases to the World Organization for Animal Health (OIE, 2011).

The knowledge of a parasite's life cycle is crucial for control, eradication and prevention of disease emergence. Investigations carried out during these

* Corresponding author. IFREMER, Laboratory of Genetics and Pathology, Av de Mus de Loup, 17390 La Tremblade, France. E-mail: Isabelle.arzul@ifremer.fr last 30 years have contributed to improve our knowledge of the parasite $M$. refringens (Comps, 1970; Grizel et al. 1974; Comps et al. 1982; Villalba et al. 1993; Le Roux et al. 1999; Berthe et al. 2000; Audemard et al. 2002; Lopez-Flores et al. 2004). However, its life cycle remains partly unelucidated. Several authors have suspected the involvement of an intermediate host in the transmission of the parasite from infected to naive oysters (Berthe et al. 1998). During studies performed in natural oyster ponds named 'claires', the calanoïd copepod Paracartia grani appeared as a potential intermediate host of $M$. refringens. Nevertheless, experimental transmission of the parasite from infected copepods to naive flat oysters failed suggesting that additional or other species could be involved in $M$. refringens transmission (Audemard et al. 2002; Carrasco et al. $2008 a$ ). Some work carried out in open bays in the Ebre Delta, Spain, allowed detection of parasite DNA by nested PCR targeting the IGS region in several zooplanktonic species including Acartia discaudata, Acartia clausi, Acartia italica, Oithona sp., Euterpina acutifrons and larval stages of brachyura (Carrasco et al. 2007a,b).

The parasite $M$. refringens not only infects flat oysters O. edulis but also mussels Mytilus edulis 
and Mytilus galloprovincialis. Several mussel mortality events associated with $M$. refringens have been reported in Spain and in France including in Corsica (Villalba et al. 1993; REPAMO, 2005). The parasite infecting mussels called Marteilia maurini was previously considered as a distinct species from $M$. refringens infecting flat oysters. However, ultrastructural criterions on which species distinction was based were considered dubious by some authors (Villalba et al. 1993; Longshaw et al. 2001). Moreover, the analysis of the ITS-1 and IGS sequences suggested that these two parasites were conspecific and that $M$. refringens was able to infect either flat oysters or mussels (Le Roux et al. 2001; Lopez-Flores et al. 2004). Based on a dimorphism in the locus of endonuclease HhaI in the ITS-1 sequence, two types $\mathrm{O}$ and $\mathrm{M}$ were defined and can be detected by PCR-RFLP (Le Roux et al. 2001). Although $M$. refringens type $\mathrm{O}$ preferentially infects flat oysters and type $\mathrm{M}$ is mainly found in mussels, several cases of co- or cross-infections have been reported (Le Roux et al. 2001; Lopez-Flores et al. 2004; Novoa et al. 2005; Balseiro et al. 2007). Recently, a new type called Marteilia sp. type C was described in cockles Cerastoderma edule suffering mortality in the Spanish Mediterranean coast (Carrasco et al. 2012).

Thus, two main questions remain unsolved regarding the parasite $M$. refringens: (1) Which is or which are the intermediate host(s) involved in its life cycle? (2) Which are the relative taxonomic positions of $M$. refringens type $\mathrm{O}$ and type $\mathrm{M}$ ?

In order to answer these questions, we have investigated the infection dynamics in flat oysters O. edulis, mussels M. galloprovincialis and zooplanktonic species cohabiting in an endemic site for marteiliosis: Diana Lagoon in Corsica off the southern coast of France.

Diana lagoon is located in northeastern Corsica. With a yearly production of 400 tonnes of mussels ( $M$. galloprovincialis), 150 tonnes of Pacific cupped oysters (C. gigas) and 12 tonnes of flat oysters (O. edulis), it represents the main shellfish culture area of the island. Although infection with $M$. refringens is endemic in the lagoon, flat oyster reproduces naturally and has been exploited since the Roman period. Spat of mussels $M$. galloprovincialis is imported from the Venice Lagoon and grows in Corsica until being marketed. The parasite $M$. refringens was first detected by histology in Diana Lagoon in July 1984 in $58 \%$ of flat oysters collected from the natural bed and in 1986 in $8 \%$ of mussels originating from Italy and cultivated in Corsica. Since that time, the parasite has regularly been detected in flat oysters and mussels.

In this context, the monitoring of the parasite $M$. refringens was undertaken by histology in flat oysters and mussels collected monthly between June 2007 and June 2008 in Diana Lagoon. Additionally, zooplankton was collected every 2 weeks around the mussels' production site and screened by PCR. Samples found positive by PCR were selected for further PCR and in situ hybridization (ISH) tests at the species or group level in order to discriminate between true parasitism and presence of the parasite in the digestive tract or on the body surface. Lastly, diversity of Marteilia types was investigated by PCR-RFLP and sequencing.

\section{MATERIALS AND METHODS}

\section{Sampling, temperature and salinity monitoring}

Collection of flat oysters O. edulis and mussels $M$. galloprovincialis was performed by diving in Diana Lagoon every month between June 2007 and June 2008. Sampling sites within the lagoon are shown in Fig. 1. Each sampling consisted of 30 adults bigger than $6 \mathrm{~cm}$ in length for oysters and $5 \mathrm{~cm}$ in length for mussels.

Zooplankton samples were collected at least once a month during 1 year using an Acthyd net $(25 \mathrm{~cm}$ of diameter $\times 50 \mathrm{~cm}$ in length) with a $100 \mu \mathrm{m}$ mesh towed for $5 \mathrm{~min}$ at an average speed of 2.5 knots at 3-4 $\mathrm{m}$ in depth (depth at which mussels are cultivated) around the mussel ropes and near the oyster beds.

Temperature and salinity were recorded every 2 weeks using a multi $340 \mathrm{i}$ WTW probe at $1 \mathrm{~m}$ in depth which represents the depth at which mussels were collected. These data were compared with data collected between 2001 and 2011 through REPHY (REseau de surveillance du PHYtoplancton et des PHYcotoxines) and REMI (REseau de controle MIcrobiologique) networks.

\section{Biological material processing}

For bivalves, a section of tissue including gills, mantle, gonad and digestive gland was cut and fixed in $10 \%$ formalin in $0 \cdot 22 \mu \mathrm{m}$ filtered sea water (FSW) for histological observation and pieces of digestive gland were fixed in $95 \%$ ethanol for subsequent DNA extraction.

Each zooplankton sample was divided in two equal subsamples. One was fixed in 95\% ethanol for molecular analyses and the other one was fixed in $10 \%$ formalin in FSW for later identification to group or species level and ISH assays. For each sample, individuals of the main groups were sorted based on morphological characteristics.

\section{Histology}

Bivalve soft tissues were maintained in $10 \%$ formalin in FSW until they were dehydrated and embedded in paraffin for histology according to standard procedures (Howard and Smith, 1983). Paraffin blocks 


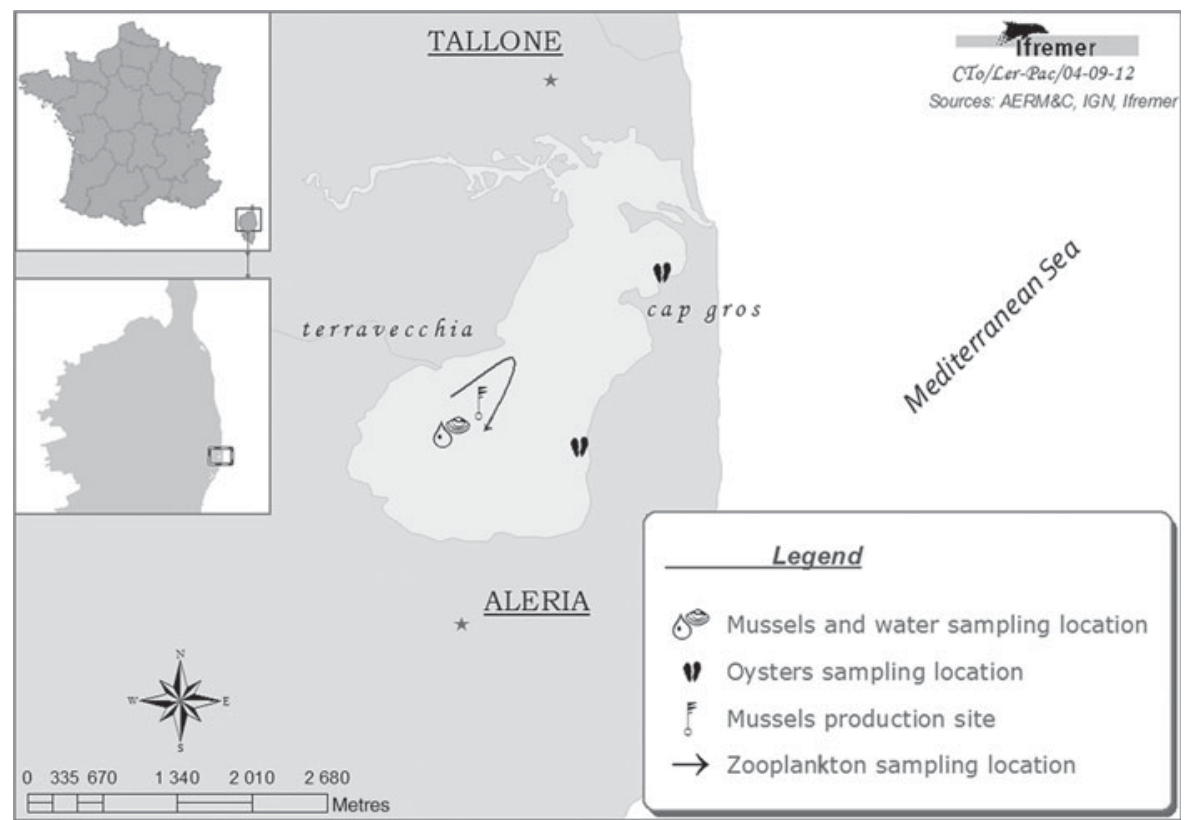

Fig. 1. Study site : Diana lagoon, North-East of Corsica, France.

were cut in $2-3 \mu \mathrm{m}$ sections and stained with haematoxylin and eosin. Infection level (from 0 to 5) was estimated according to Villalba et al. (1993).

\section{DNA extraction}

Bivalves found infected by histology were selected for molecular analyses. For these individuals, DNA was extracted from digestive gland using the QIAamp DNA minikit (Qiagen) according to the manufacturer's instructions. DNA was eluted and resuspended in a final volume of $50 \mu \mathrm{L}$ of sterile deionized water and then diluted at a final concentration of $100 \mathrm{ng} \mu \mathrm{L}^{-1}$.

DNA was extracted from bulk or sorted zooplankton samples according to the same protocol after two baths in phosphate buffered saline (PBS) $1 \times$.

\section{PCR, PCR-RFLP, cloning and sequencing}

In order to detect and characterize parasites isolated during this study, two PCR assays targeting sequences of rDNA internal transcribed spacer region (ITS) and intergenic sequence (IGS) were used according to Le Roux et al. (2001) and Lopez-Flores et al. (2004) respectively. In addition, for zooplankton samples, a PCR assay using eukaryotic 'universal' primers CS1-CAS1 and amplifying about $780 \mathrm{bp}$ of the $18 \mathrm{~S}$ ribosomal DNA was used to verify the absence of PCR inhibitors according to Le Roux et al. (1999). Negative PCR controls consisting of water were included with every 10 tested samples in order to check for potential contamination. Positive PCR controls corresponding to DNA extracted from oysters and mussels previously found infected with
$M$. refringens type $\mathrm{O}$ and type $\mathrm{M}$ were included in each PCR test.

Parasite type was firstly determined using the PCR-RFLP approach developed by Le Roux et al. (2001).

Representative PCR products of different PCRRFLP profiles were cloned using the original TOPO TA cloning kit (Invitrogen) according to manufacturer's recommendations and positive clones were then selected for plasmid DNA purification by FastPlasmid ${ }^{\circledR}$ Mini (Eppendorf). Some plasmidic DNA suspensions were bidirectionally sequenced using the Big Dye V3 sequencing kit (Applied Biosystem) and standard M13 forward and reverse primers. Obtained sequences were compared with those included in GenBank using the BLASTn algorithm (Altschul et al. 1997).

\section{Sequence analyses}

Some available ITS1 sequences from Marteilia spp. were downloaded from GenBank (DQ426611, DQ426550 and JN820085 as representatives of $M$. refringens types $\mathrm{O}, \mathrm{M}$ and $\mathrm{C}$ respectively) and included in the phylogenetic analysis with sequences obtained in the present study. Alignments were performed using Clustal W (Thompson et al. 1994) including in MEGA 5 with open and extend gap penalties of 7 and 3, respectively.

Phylogenetic analysis was performed using the Neighbour-joining method (Saitou and Nei, 1987) and the evolutionary distances were computed based on the Tajima-Nei distance (Tajima and Nei, 1984) under MEGA5 package (Tamura et al. 2011). The analysis involved 15 nucleotide sequences and 
a total of 362 positions in the final dataset. Bootstrap values were calculated over 1000 replicates.

Genetic distance corresponding to the number of base substitutions per site from averaging over all sequence pairs was estimated using the Tajima-Nei model ('Tajima and Nei, 1984) in MEGA 5 (Tamura et al. 2011).

\section{In situ hybridization}

After species sorting, PCR positive zooplankton samples were tested by ISH according to a protocol adapted from Le Roux et al. (1999). Five $\mu$ m thick tissue sections on silane-prep ${ }^{\mathrm{TM}}$ slides (Sigma, France) were dewaxed, rehydrated and treated with proteinase $\mathrm{K}\left(100 \mu \mathrm{g} \mathrm{mL}^{-1}\right.$ in TE buffer [Tris $50 \mathrm{~mm}$, EDTA $10 \mathrm{~mm}]$ ) at $37^{\circ} \mathrm{C}$ for $5 \mathrm{~min}$. Slides were dehydrated by immersion in an ethanol series and air-dried. Sections were then incubated with $100 \mu \mathrm{L}$ of hybridization buffer (50\% formamide, $10 \%$ dextran sulfate, $4 \times \mathrm{SSC}[0.06 \mathrm{M} \mathrm{Na}$ citrate, $0.6 \mathrm{M}$ $\mathrm{NaCl}, \mathrm{pH} 7], 250 \mu \mathrm{g} \mathrm{mL}^{-1}$ yeast tRNA and $10 \%$ Denhardt's solution) containing $10 \mathrm{ng} \mu \mathrm{L}^{-1}$ of the digoxigenin-labelled probe, called SMART2 specific for the $18 \mathrm{~S}$ rRNA gene of $M$. refringens (Le Roux et al. 1999). Target DNA and digoxigenin-labelled probe were denatured at $95^{\circ} \mathrm{C}$ for $5 \mathrm{~min}$ and the hybridization was carried out overnight at $42^{\circ} \mathrm{C}$. Sections were washed in $2 \times \mathrm{SSC}$ at room temperature $(\mathrm{RT})(2 \times 5 \mathrm{~min})$, in $0.4 \times \mathrm{SSC}$ at $42^{\circ} \mathrm{C}(10 \mathrm{~min})$ and in solution I (100 mM maleic acid, $0 \cdot 15 \mathrm{M} \mathrm{NaCl}$, $\mathrm{pH} \mathrm{7 \cdot 5)}$ for $5 \mathrm{~min}$. Tissues were then blocked for 30 min at RT with blocking reagent (Amersham Life Science) $(1 \% \mathrm{w} / \mathrm{v})$ in solution I. Specifically bound probe was detected using an alkaline phosphataseconjugated mouse $\mathrm{IgG}$ antibody against digoxigenin diluted at $1.5 \mathrm{U} \mathrm{mL}^{-1}$ in solution I ( $\left.1 \mathrm{~h}, \mathrm{RT}\right)$. Excess of antibody was removed by two washes in solution I $(1 \mathrm{~min})$ and one wash in solution II $(0 \cdot 1 \mathrm{M}$ Tris $\mathrm{pH} 8$, $\left.0 \cdot 1 \mathrm{M} \mathrm{NaCl}, 0.05 \mathrm{M} \mathrm{MgCl}_{2}, \mathrm{pH} 9 \cdot 5\right)$. Slides were incubated in NBT/BCIP, a chromogenic substrate for alkaline phosphatase, diluted in solution II $\left(20 \mu \mathrm{L} \mathrm{mL}^{-1}\right)$ in the dark until the parasitic cells were completely stained black-purple. The reaction was stopped with solution III $(100 \mathrm{~mm}$ Tris, $1 \mathrm{~mm}$ EDTA, pH 8). Slides were counterstained for $1 \mathrm{~min}$ with Bismarck brown yellow $\left(5 \mathrm{mg} \mathrm{mL}^{-1}\right)$, dehydrated with ethanol and mounted in Eukitt resin. Negative controls included samples without digoxigenin-labelled probe in hybridization mixture or without antibodies during colour development. Positive control consisted of sections from flat oysters O. edulis infected with $M$. refringens originating from Thau lagoon (France).

\section{Statistical analyses}

Statistical analyses were performed using the Rcmdr package under $\mathrm{R}$ ( $\mathrm{R}$ Core Development
Team, 2009). Linear regression model was used to test the potential effect of environmental parameters including temperature and salinity on prevalence. Pearson's product-moment correlation coefficient was also calculated between prevalence and salinity or temperature.

\section{RESULTS}

\section{Temperature and salinity monitoring}

Data obtained between June 2007 and June 2008 are shown in Fig. 2A and B.

Water temperature fluctuated between $9.3^{\circ} \mathrm{C}$ (in December 2007) and $28 \cdot 4^{\circ} \mathrm{C}$ (in July 2007). Temperature was maximum in July-August 2007 and then decreased until January 2008. In wintertime, temperature stagnated around $10^{\circ} \mathrm{C}$ before increasing between March and June 2008 (Fig. 2A). Temperatures recorded in the context of this study generally appeared in the range of values recorded between 2001 and 2011 but sometimes appeared higher or lower than the first or third quartiles especially when temperature was recorded late in the month.

Due to the permanent connection with the sea and the low contributions of fresh water, salinity presented small fluctuations between $34 \cdot 4$ and $39 \cdot 5$ (Fig. 2B). However, three exceptional salinity decreases related to important rainfalls were recorded in November 2007, January and April 2008. Salinity measured between June 2007 and June 2008 was within the data range over the period 2001-2011 except in January and June 2008.

\section{Marteilia refringens dynamics in bivalves and zooplankton samples}

Histological examination of flat oysters did not allow the detection of $M$. refringens in all the tested oysters.

Histological examination of 358 mussels revealed the presence of the parasite in 55 individuals in samples collected from June 2007 to March 2008. Mussels collected between April and June 2008 did not appear infected with $M$. refringens (Fig. 3A). Depending on the sampling date, detection frequency fluctuated between 0 and 83\% (Fig. 3A).

Parasite detection was higher during summertime (June-August 2007) compared with autumn and winter. Transition between these two periods was associated with a sudden decrease of detection frequency from $83 \%$ in August to 3\% in September 2007.

Neither temperature nor salinity appeared to significantly influence prevalence $(P=0.096$ and $P=0 \cdot 144$, respectively); however, Pearson's product-moment correlation coefficients were positive 


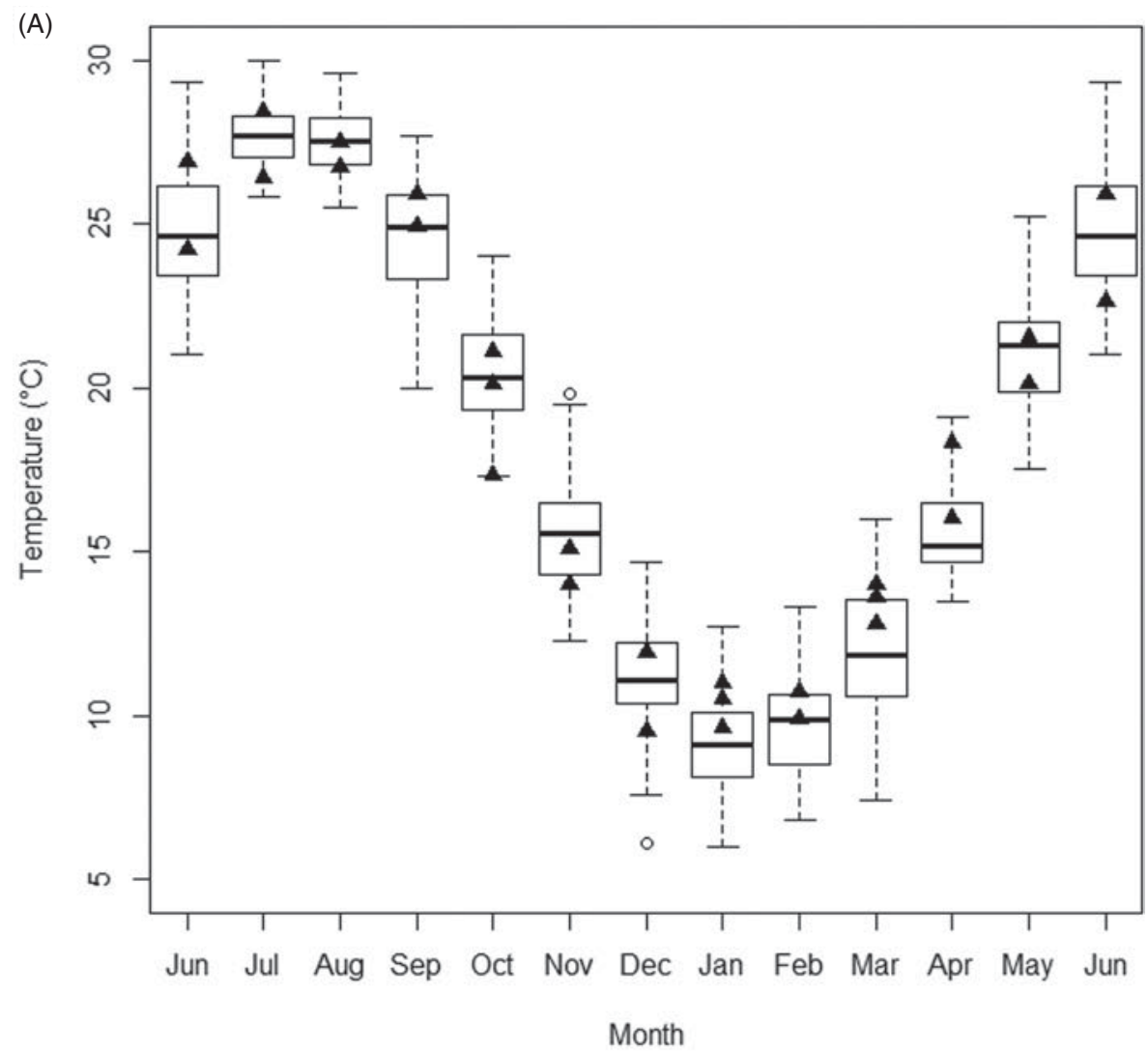

(B)

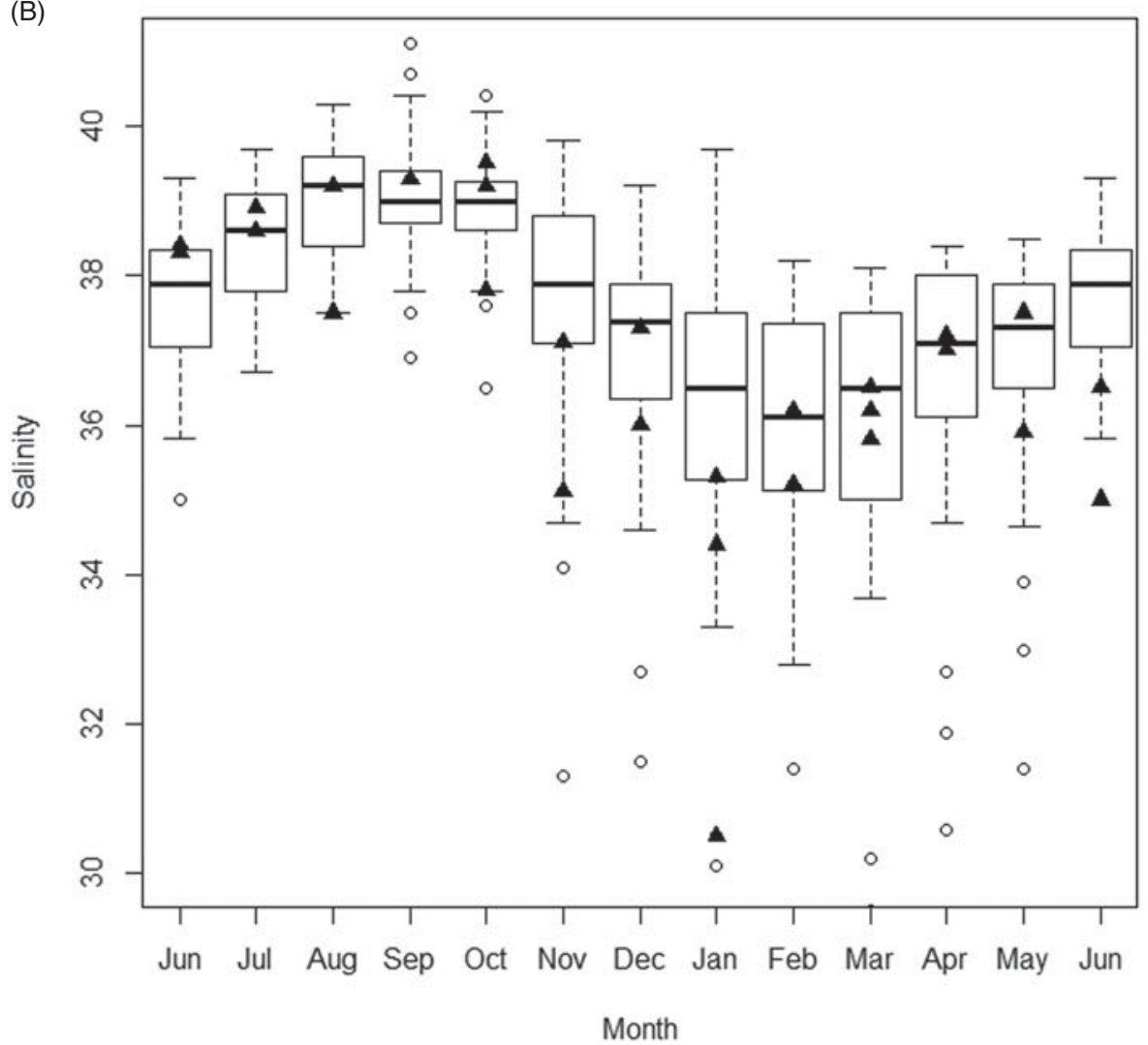

Fig. 2. (A) Temperature $\left({ }^{\circ} \mathrm{C}\right)$ in Diana lagoon between June 2007 and June 2008 (dark triangles). Box plots indicate data collected at the same location between 2001 and 2011 through REPHY (REseau de surveillance du PHYtoplancton et des PHYcotoxines) and REMI (REseau de controle MIcrobiologique) networks. Open circles indicate outliers; (B) Salinity in Diana lagoon between June 2007 and June 2008 (dark triangles). Box plots indicate data collected at the same location between 2001 and 2011 through REPHY (REseau de surveillance du PHYtoplancton et des PHYcotoxines) and REMI (REseau de controle MIcrobiologique) networks. Open circles indicate outliers. 

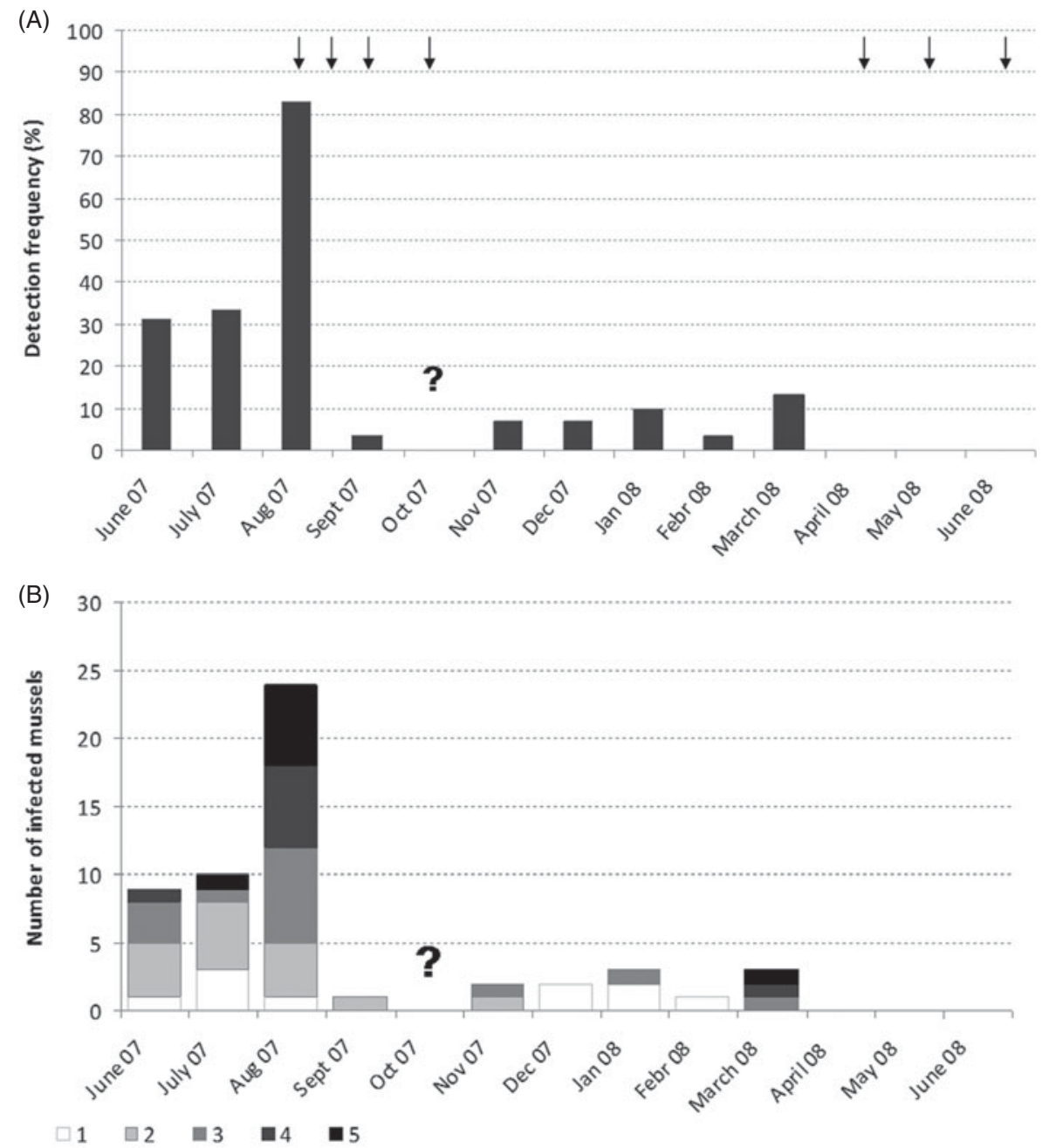

(C)

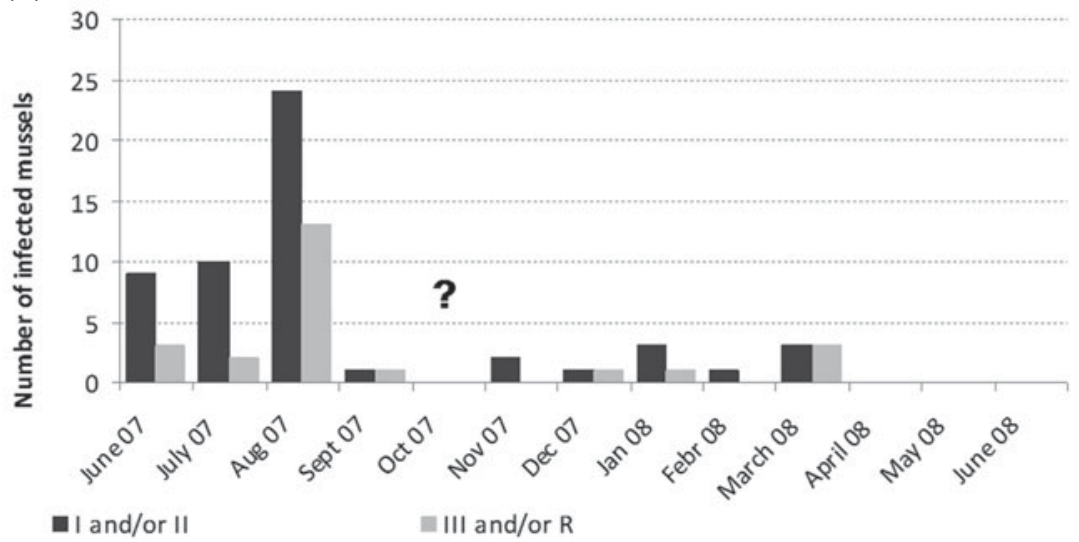

Fig. 3. (A) Detection frequency of the parasite Marteilia refringens by histology in mussels (histograms). No sampling was performed in October 2007 because of bad weather conditions (the lack of data is indicated with the question mark). Arrows indicate zooplankton samples found positive by nested PCR; (B). Infection intensity (1-5) in infected mussels using the scale of Villalba et al. (1993). No sampling was performed in October 2007 (the lack of data is indicated with the question mark); (C) Evolution of parasite stages in infected mussels. No sampling was performed in October 2007 (the lack of data is indicated with the question mark). I, II and III correspond to primary, secondary and tertiary stages respectively. $\mathrm{R}$ corresponds to refringent stages.

and moderate, $0 \cdot 45$ and $0 \cdot 5$ between prevalence and salinity or temperature, respectively.

Infection intensity in mussels, estimated according to Villalba et al. (1993), was high (levels 4 and 5) between June and August 2007 and then in March 2008 , whereas it was moderate (level 3) or low (levels 1 and 2) between September 2007 and February 2008 (Fig. 3B). 
(A)

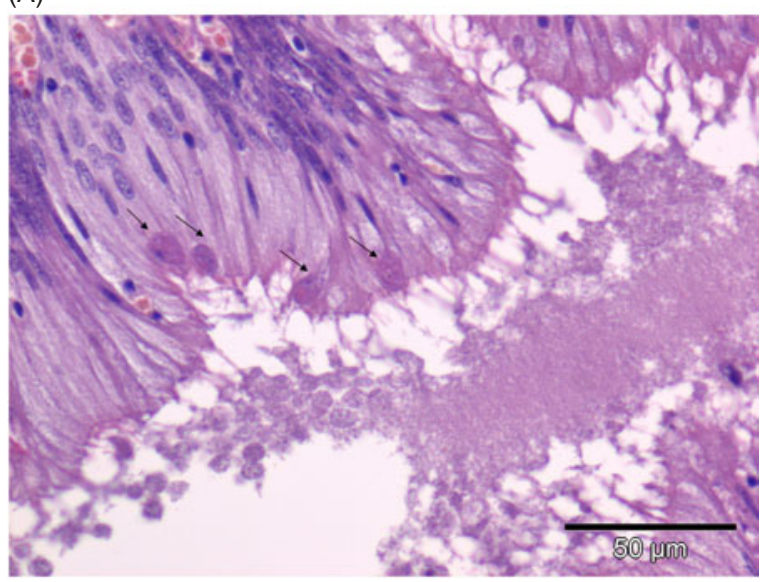

(B)

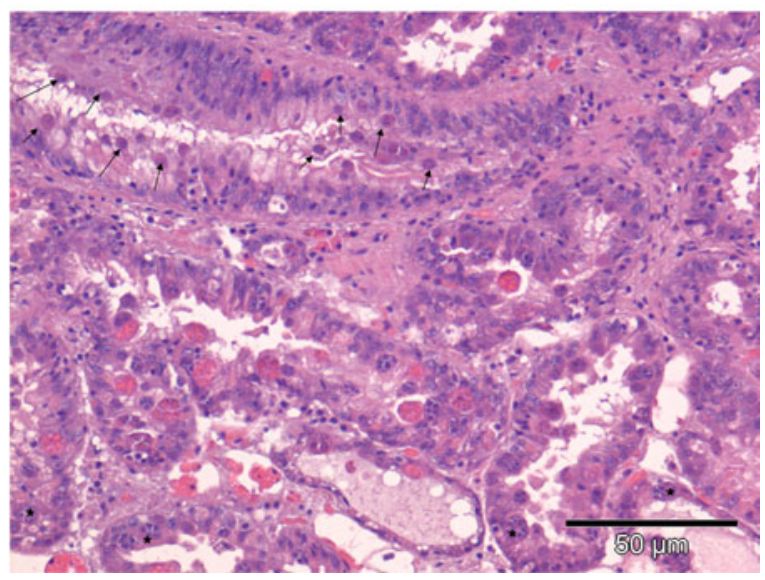

Fig. 4. Haematoxylin and eosin stained histological section from mussels Mytilus galloprovincialis infected with Marteilia refringens. (A) Low infection level: primary-secondary stages (arrows) are observed in the epithelium of the stomach; (B) High infection level: young stages (arrows) are observed in the epithelium of a digestive duct and mature stages (stars) are located in digestive diverticula epithelium.

Developmental stages of the parasite were also recorded (Fig. 3C). When intensity level was high, first maturation stages and zoosporangia were detected in most of the digestive diverticula and a few parasites including primary and secondary parasite stages were observed in the epithelium of the stomach (Fig. 4A and B). Conversely, when infection intensity was low, mainly young stages were located in the stomach epithelium.

Zooplankton samples were first tested by PCR using the eukaryotic universal primers. All the 23 samples yielded positive results and were subsequently tested by the nested PCR targeting the IGS region of the parasite genome. On the 23 tested samples seven showed PCR products at the expected size $(358 \mathrm{bp})$. Four of these positive samples were collected between mid-August and mid-October while the other positive samples were collected in spring (Fig. 3A).
Zooplankton diversity in M. refringens-positive PCR samples and parasite detection in sorted zooplankton samples

PCR-positive formalin-fixed zooplankton samples were selected in order to identify and sort the main abundant taxa. Different zooplankton groups were observed in the PCR-positive samples (Table 1): Copepods, Appendicularia, Cladocera, Chaetognatha, Polychaeta (larvae), Decapoda (larvae), Echinoderm larvae, Cirripedia nauplii and fish eggs.

All the sorted taxa were then processed for DNA extraction and tested by PCR using universal primers and $M$. refringens specific PCR primers.

Except for one sample of Decapoda larvae (30/4/ 2008), all tested samples yielded amplification products using the universal primer pair.

Marteilia refringens-specific PCR results are summarized in Table 1. For three taxa, positive results were obtained for all the tested samples (Paracartia latisetosa, Oithona sp. and Evadne sp.) and for three other taxa, negative results were obtained for all tested samples (nauplii of Cirripedia, larvae of Echinoderm and anchovy eggs). Copepods Centropages typicus, Appendicularia, larvae of Polychaeta, Cladocera Penilia avirostris and Chaetognatha Sagitta sp. presented at least one positive sample each. Zooplankton organisms that were positive for $M$. refringens by PCR were selected for ISH. Several sections from each paraffin block were tested each time. Positive specific labelling was observed in two individual $P$. latisetosa. Positive cells were numerous, small $(1-2 \mu \mathrm{m})$ and located within the gonadal tissues of female copepods (Fig. 5A-C). Some copepod ovocytes appeared full of these multiple small cells.

\section{Molecular characterization of M. refringens detected in mussels and zooplankton samples}

Mussels found to be infected by histology and bulk zooplankton samples found positive by nested PCR were selected for further molecular characterization work.

All the 55 mussels found infected by histology appeared positive by PCR using PR4-PR5 primers. Digestion of PR4-PR5 PCR products (Le Roux et al. 2001) produced two types of RFLP profiles in 53 mussels (two PCR products were too faint to be digested): type $M$ was observed in 51 mussels while profiles of both types were observed in two mussels collected in June 2007. PCR products from these two mussels and one mussel showing type $M$ profile were cloned. Two to three clones per mussel were sequenced. A total of eight sequences were obtained among which five displayed 99-100\% homology with $M$. refringens type M (DQ426550) and three showed $99 \%$ homology with $M$. refringens type O (DQ426611). 
Table 1. Zooplankton taxa identified in the seven samples (one sample = one column) found PCR positive. When a taxa is present, the cell is coloured in grey. PCR results are indicated using letters: $\mathrm{U}$ (Undetermined) when PCR using universal primers was negative; N (Negative) when PCR using universal primers was positive and PCR using specific primers was negative; P (Positive) when PCR assays using universal and specific primers were positive

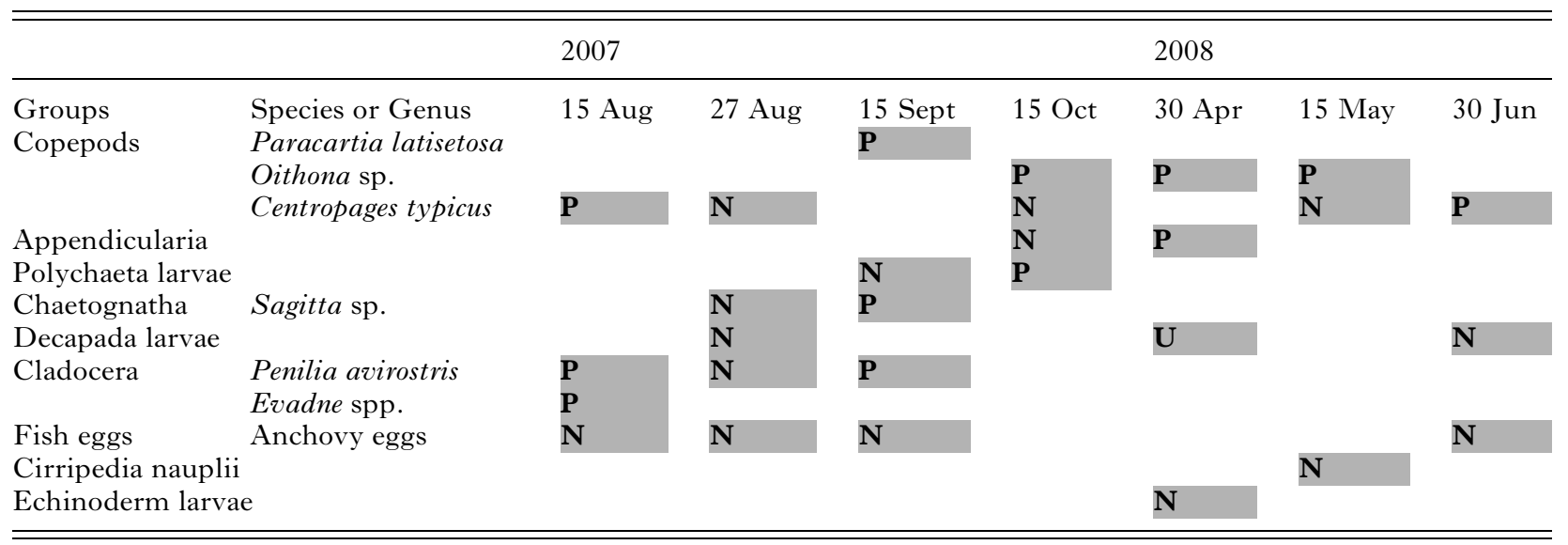

For zooplankton, on the seven samples found positive by nested PCR, two appeared positive by PCR using PR4-PR5 primers. These two PCR products were too faint to be directly digested and were ligated in Topo A vector for cloning. Four clones obtained from zooplankton samples were sequenced among which two had 99\% homology with $M$. refringens type M (DQ426550) and two sequences showed 96\% homology with Marteilia sp. type C (JN820088).

Alignment of obtained sequences with three sequences downloaded from Genbank is shown in Fig. 6. Hha I restriction sites are highlighted in yellow. As expected, restriction sites used to discriminate between types $\mathrm{O}$ and $\mathrm{M}$ are present in the sequences showing maximum homology with $M$. refringens types $\mathrm{O}$ and $\mathrm{M}$. However, sequences close to Marteilia sp. type C (JN820085) show restriction sites close to type $\mathrm{M}$ ones. An additional site is observed in $07 / 69$ clone 1 due to a substitution of a 'A' by a 'G'.

Overall mean distance among all tested sequences was 0.069 whereas distances within each type sequences were below 1\%: 0.004 for types $\mathrm{M}$ and $\mathrm{O}$ and 0.005 'type $\mathrm{C}$ ' sequences. Most of the polymorphism consisted in point substitutions observed in only one clone or one downloaded sequence. Distance between types $\mathrm{M}$ and $\mathrm{O}$ sequences $(0 \cdot 018)$ was lower than between type $\mathrm{C}$ and other types $(0 \cdot 07$ and $0 \cdot 107$ with types $\mathrm{M}$ and $\mathrm{O}$ respectively).

The phylogenetic analysis using the Neighbourjoining method showed three distinct groups corresponding to types $\mathrm{M}, \mathrm{O}$ and $\mathrm{C}$ (Fig. 7).

\section{DISCUSSION}

Considering the simultaneous presence of flat oysters, mussels and the parasite in Diana lagoon and the probable involvement of zooplankton in its transmission, the study presented herein investigated $M$. refringens dynamics in bivalves and zooplankton in order to better understand the parasite cycle.

None of the 360 tested flat oysters appeared infected with the parasite $M$. refringens during the period of study. Considering the small sample size (30 animals per month), the lack of detection of the parasite might be due to a very low prevalence of the disease. However, the parasite was regularly detected in the oyster population between 1984 and 1988 and then in 2002 and 2005 (Pichot, 2002; REPAMO, 2007). Detection frequencies reported in the 1980 s ranged between $32 \%$ and $100 \%$ while in 2002 and 2005 they were between $0 \%$ and $13 \%$ (REPAMO, unpublished data). Considering that the oyster production in the lagoon relies only on natural reproduction and that no change in culture practices was reported, this apparent prevalence decrease could be due to the development of natural resistance to marteiliosis in the oyster population. However this hypothesis would need further investigation.

In contrast to flat oysters, mussels appeared infected with Marteilia sp. between June 2007 and March 2008 with detection frequencies fluctuating seasonally up to $83 \%$ in August 2007. These results suggest a lack of parasite transmission between mussels and flat oysters which can be due to distance between mussel and flat oyster sampling sites or to a stricter host specificity of the parasite than expected.

Previous studies carried out in locations where both flat oysters $O$. edulis and mussels $M$. galloprovincialis were present showed differing situations regarding infection with $M$. refringens. In Galicia, Spain, flat oysters cultured in the same raft as Marteilia-infected mussels, with prevalences of up to $73 \%$, remained free of the parasite (Figueras and Robledo, 1993). Similarly, in Croatia, the parasite 
(A)

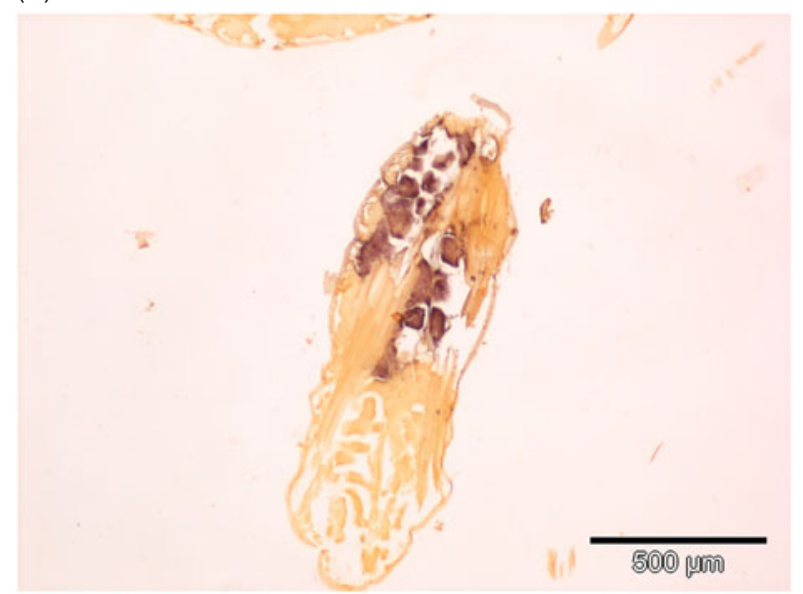

(B)

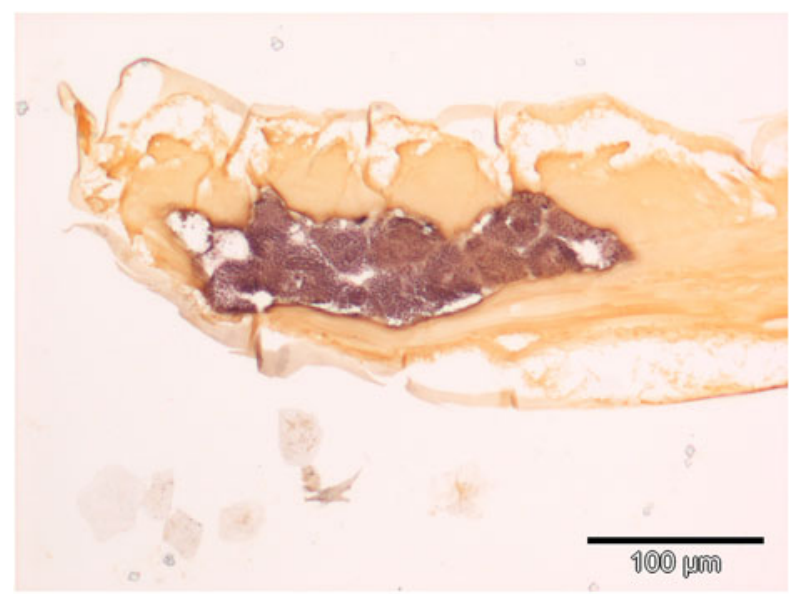

(C)

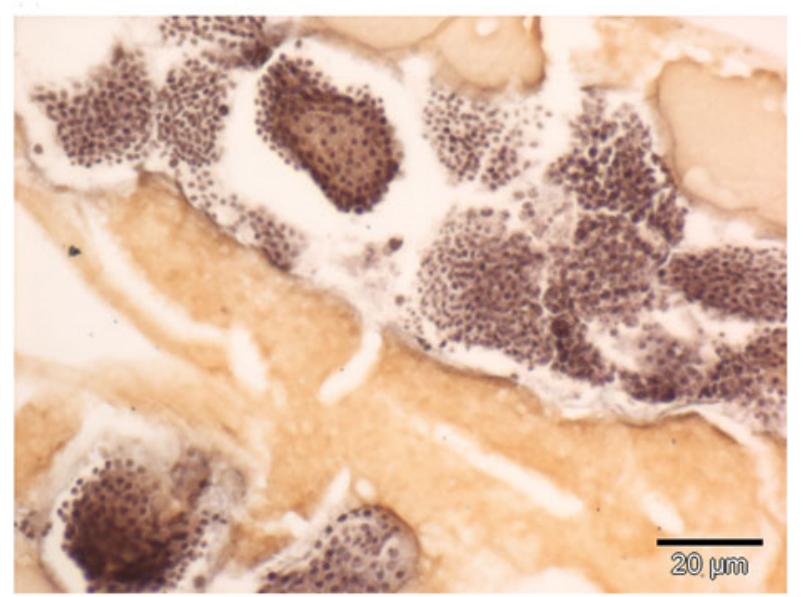

Fig. 5. In situ hybridization analysis of copepods

Paracartia latisetosa. (A) Positive labelling is observed in small cells $(1-2 \mu \mathrm{m})$ located in the gonadal tissue of a female copepod; (B) All the gonad seems affected by the presence of these positive cells; (C) Positive cells are arranged in clusters and can be observed in a copepod ovocyte (arrow).

was only detected in mussels with low prevalence $(5 \%)$ while no infected flat oysters were found (Zrncic et al. 2001). In the Thermaikos gulf in Northern Greece, a study performed on bivalves including flat oysters and Mediterranean mussels showed infection with $M$. refringens in both species with $60 \%$ and $21 \%$ of detection frequency respectively (Virvilis et al. 2003). Lastly, sporadic detection of the parasite was reported in both species from different geographic origins in Alfacs and Fangar bays in Ebre Delta in Catalonia Spain (Carrasco et al. 2008b).

Seasonality of Marteilia sp. dynamics in mussels in Diana lagoon appeared weakly positively related to temperature and salinity. In summer, between June and August 2007, the number of infected mussels increased as did infection intensity. The increase of infected mussels was probably due to transmission of the parasite with more mussels exhibiting young parasite stages. During this period, the number of infected mussels showing high infection levels and mature parasite stages increased suggesting a development of the infection in these bivalves. These highly infected mussels displayed more young parasite stages not only in the stomach epithelium but also in the epithelium of digestive ducts, suggesting that these primary stages could migrate along the digestive system. In September 2007, only one mussel was found infected. Considering that mussel sampling was performed on the same cohort and that no mortality was reported in this population (Bouchoucha, personal communication), the dramatic decrease of detection frequency observed between August and September suggests that the parasite, all stages included, was successfully degraded by mussels or released outside the mussels. Similarly, in a study carried out in different sites in Galicia, the variation in the prevalence of the infection was better explained by an elimination of the parasite via the action of the mussel's defence mechanisms rather than by death of infected mussels (Robledo and Figueras, 1995). In Diana lagoon, after the important decrease of prevalence, the number of infected mussels remained low with variable infection intensity. Refringent stages, which contain refringent granules and spores, were observed in December, January and then March. These results suggest that the parasite sporulates all year long but more importantly when temperature is highest. Seasonality in the parasite dynamics was previously reported, for example in mussels in the Ebre Delta where a positive correlation between detection frequency and temperature was observed (Carrasco et al. 2007a), and in flat oysters in France where increased infection was associated with sporulation of the parasite and a peak in oyster mortalities (Grizel and Tigé, 1973; Alderman, 1979; Balouet et al. 1979; Grizel, 1985). However, no clear temporal pattern of infection was observed in mussels in Galicia (Villaba et al. 1993; Robledo and Figueras, 1995) where prevalence of the parasite changed with site and year.

Zooplankton samples collected between August and October 2007 and then between April and June 2008 were positive by $M$. refringens-specific PCR. 

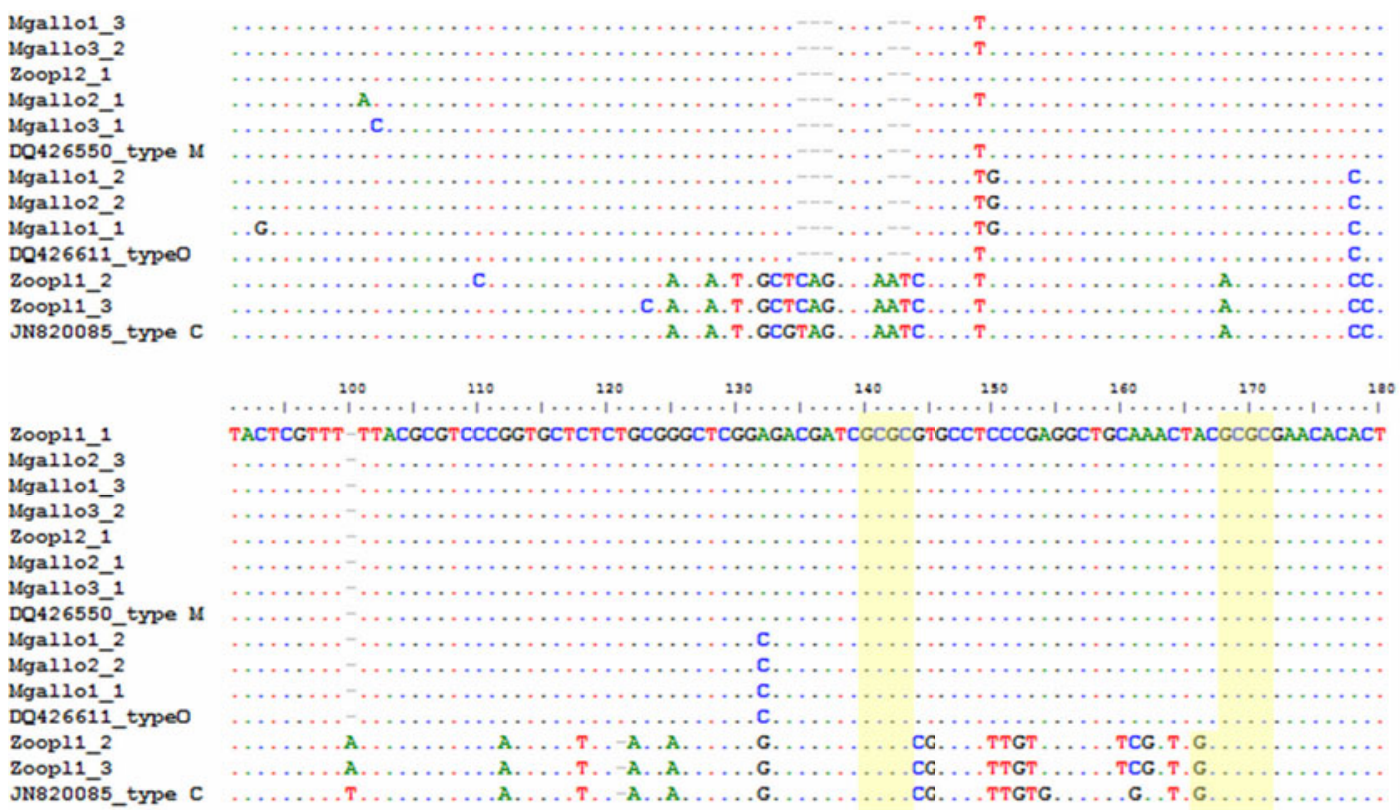

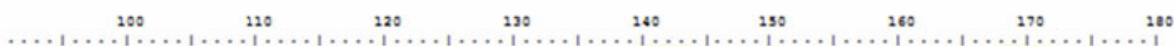
TACTCGTTT-TTACGCGTCCCGGTGCTCTCTGCGGGCTCGGAGACGATCGCGCGTGCCTCCCGAGGCTGCAAACTACGCGCGAACACACT

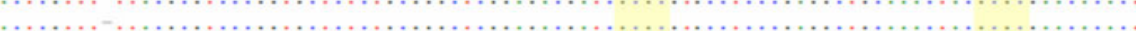

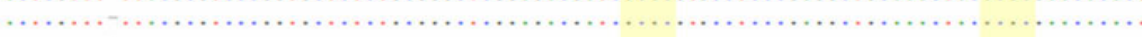
(....... …… n.

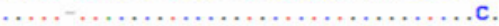

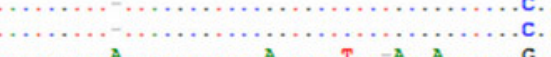

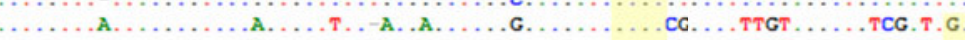

Zoopl1_JN820085_type C

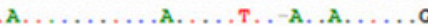

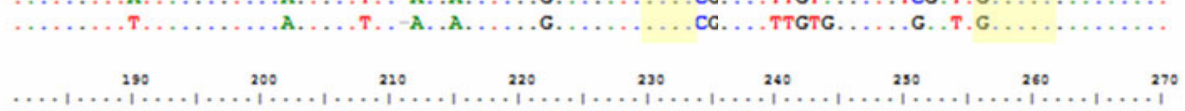
Ugal1 $10 \overline{2}_{3}$

Ugallo2 3

Mgallo1_3

Igallo3-2

2oop12_1

Mgallo ${ }^{2}{ }_{1}$

Mgallo3_1

DQ426550_type U

Mgallo1_2

Mgallo2 2

Ugal101-1

DQ426611_typeO

Zoop11_2

Zoop11_3

JN820085_type C

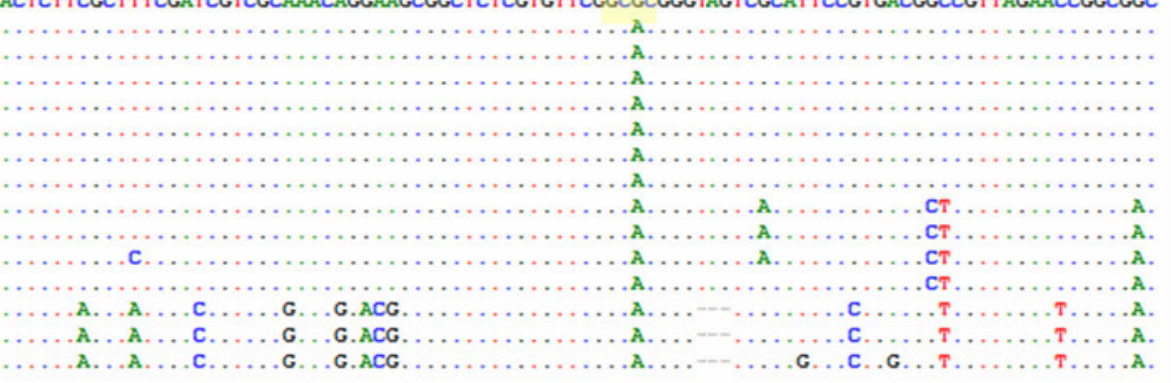

30

$340 \quad 3290 \quad 260$

Zoopl1_1
Ugallo2_3
Ugallo1_3
Ugallo3-2
Zoop12_1
Ugallo2_1
Ugal103_1
DQ426550_type M
Ugallo1_2
Ugallo2_2
Ugallo1_1
DQ426611_typeO
Zoop11_2
Zoopl1_-3
JN820085_type C

ATTATCGTGTCGTCGTAGACGATAGCACGGTACAGCCAGGCGAGTGCTCTCGTTCCGCTTGCCCT-ACGGCCGTGCTGCGTCGAACAGCT

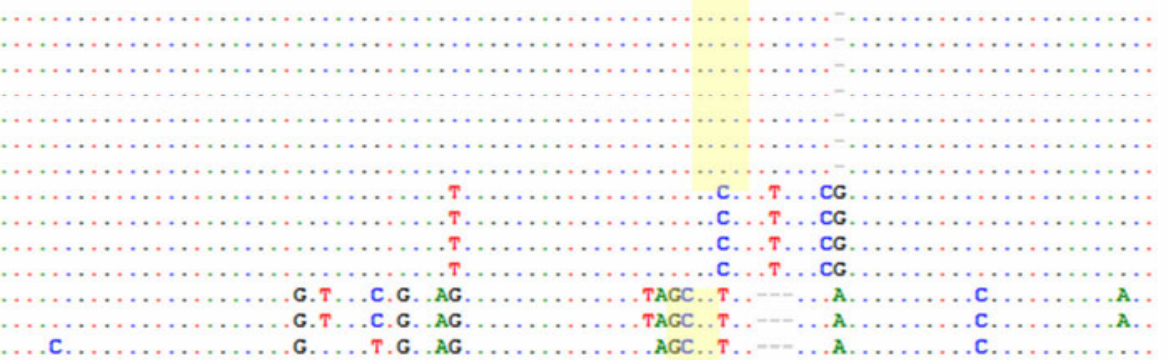

370

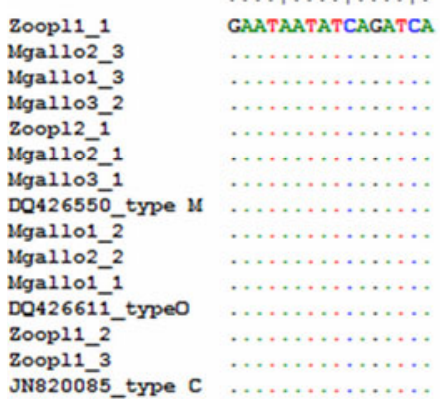

Fig. 6. Alignment of sequences obtained in the present study (corresponding accession numbers are given in Table 2) with three sequences from GenBank (DQ426550 for Marteilia refringens type M; DQ426611 for Marteilia refringens type O; JN820085 for Marteilia sp. type C). HhaI restriction sites are boxed in yellow. 


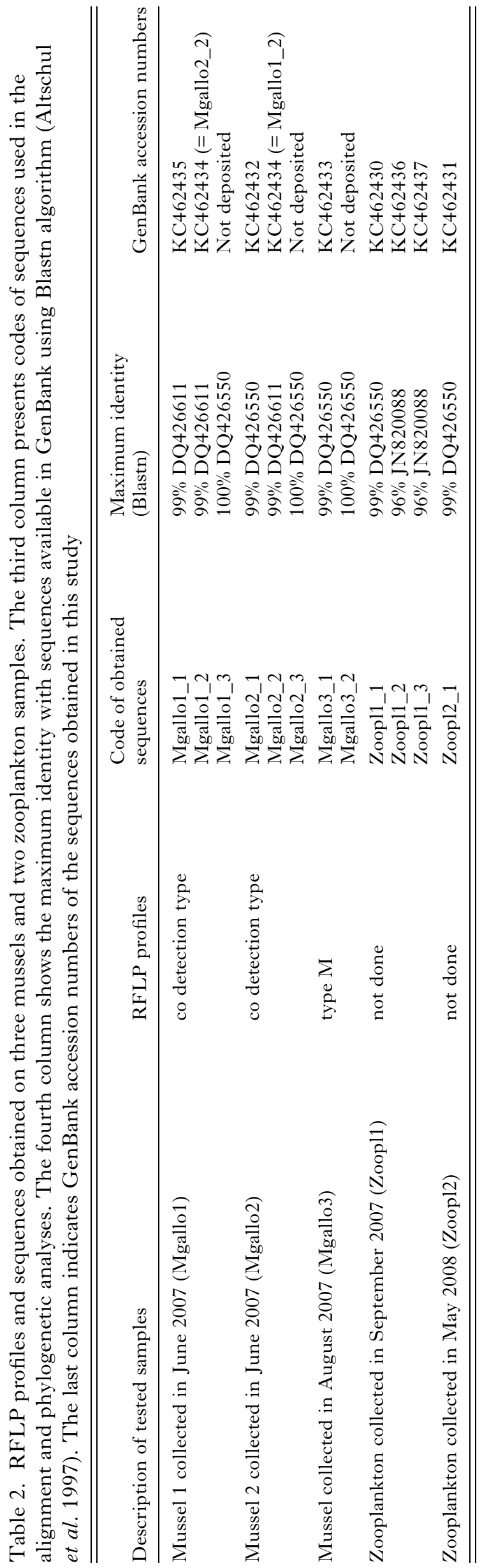

Detection by PCR indicates presence of $M$. refringens DNA and does not necessary mean true infection (Burreson, 2008). However, the first period of detection in zooplankton coincided with a precipitous decline in prevalence of the parasite in mussels and could correspond to a transmission of the parasite from mussels to zooplankton. This first period is followed by a lack of detection in zooplankton and low detection frequency in mussels. Berthe et al. (1998) hypothesized that the parasites could mature in the sediment after being released from oysters to the water column. The detection of $M$. refringens in zooplankton from April 2008 could be related to an increase of water temperature, above $17^{\circ} \mathrm{C}$, allowing new zooplankton infection or parasite development in zooplankton reaching an infection level detectable by PCR. Contrary to a previous study carried out in the Ebre Delta (Carrasco et al. 2007a), no positive signal was obtained in zooplankton collected in Diana lagoon before the peak of prevalence observed in mussels in August in our study. Our results support the hypothesis of the transmission of the parasite from mussels to zooplankton but not from zooplankton to mussels. They are in agreement with previous experiments which succeeded in transmitting $M$. refringens from infected flat oysters and infected mussels to the copepod $P$. grani but failed in transmitting the parasite from infected copepods to naive bivalves (Audemard et al. 2002; Carrasco et al. 2008a).

Zooplankton samples found positive by $M$. refringens-specific PCR were selected for further work in order to identify and sort the main abundant species present in these samples.

The quality of DNA extracted from the different sorted taxa was confirmed with conserved primers except in one sample of Decapoda larvae. For some taxa, all the tested samples appeared negative by PCR specific to $M$. refringens. These taxa, including Cirripedia, Echinoderm larvae and Anchovy eggs might not be involved in the parasite cycle. On the contrary, taxa for which positive results were obtained for all the tested samples such as P. latisetosa, Oithona sp. and Evadne sp. might more probably be involved in the parasite transmission. Some similar taxa were previously found to be positive by PCR in other ecosystems including decapod larvae in claire ponds (Audemard et al. 2002) and Oithona sp. in the Ebre Delta (Carrasco et al. 2007b).

All the zooplankton species and groups found positive by PCR for the detection of $M$. refringens were tested by ISH in order to discriminate between true parasitism and presence of $M$. refringens in the digestive tract or on the body surface. Several sections from each paraffin block were tested for the detection and localization of the parasite. One species, $P$. latisetosa presented specific labelling in the female gonadal tissues. Other paramyxean species are known 


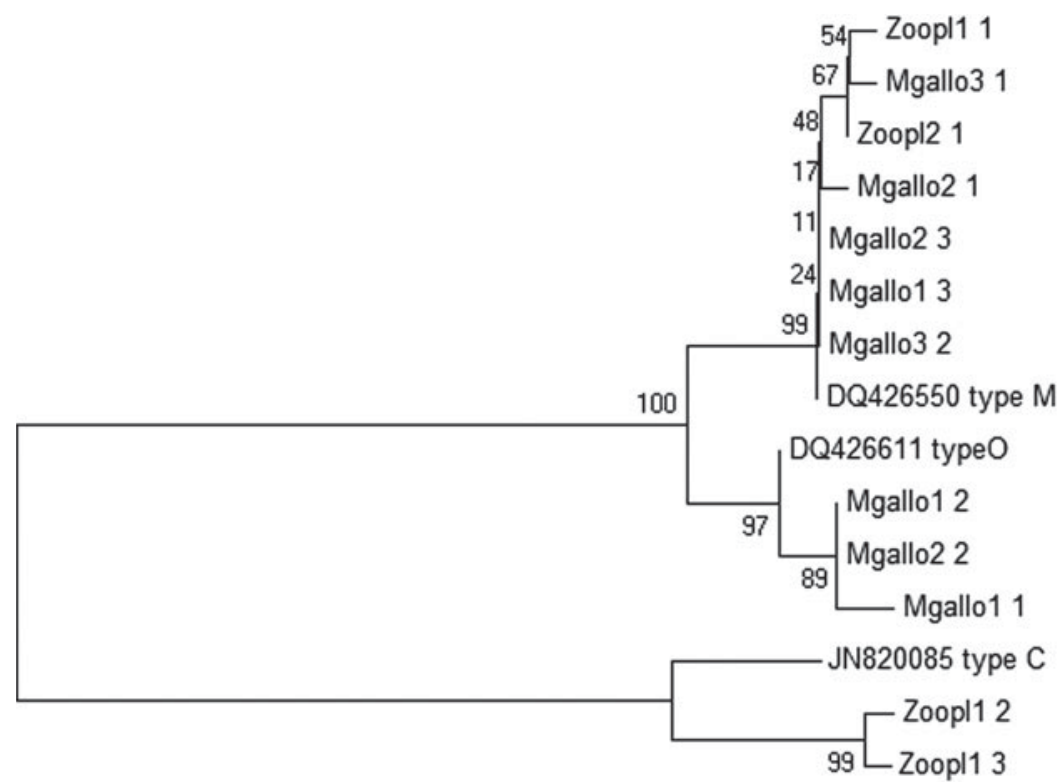

0.02

Fig. 7. Phylogenetic tree performed using the Neighbour-joining method based on the Tajima-Nei distance deduced from 12 rDNA ITS1 sequences of Marteilia refringens obtained from three mussels and two zooplankton samples collected in Diana lagoon and three sequences downloaded from GenBank (DQ426550 representative of type M, DQ426611 representative of type O and JN820085 representative of type C). Numbers at nodes indicate bootstrap values. Corresponding accession numbers for sequences obtained in the present study are given in Table 2.

to target gonads in marine invertebrates: Marteilioides chungmuensis in C. gigas (Comps et al. 1986) and Paramarteilia orchestiae in Orchestia gammarellus (Ginsburger-Vogel and Desportes, 1979). These parasites could be released outside their host through the gonadal duct or be released with eggs during spawning. The numerous small cells observed inside or instead of $P$. latisetosa ovocytes suggest that the parasite develops and multiplies within the ovocytes. A similar observation was reported in copepods $P$. grani collected from claire ponds (Audemard et al. 2002) where large numbers of small parasite cells were detected in ovarian tissue. Copepods P. grani experimentally infected with $M$. refringens from mussels displayed positive labelling in the digestive epithelium, while when infected with $M$. refringens from oysters the parasite was firstly found in the digestive epithelium and then in the gonad (Carrasco et al. 2008a). Our results demonstrate for the first time a true infection with $M$. refringens in a zooplankton species other than $P$. grani. In addition, these results suggest, but do not demonstrate, that $P$. latisetosa may act as an intermediate host for $M$. refringens. Members of the genus Paracartia appear as key actors in the parasite cycle, however further experimental work would be necessary to fully confirm this hypothesis. The lack of visualization of the parasite in other tested species found positive by PCR is probably due to the presence of $M$. refringens DNA in the digestive tract or on the body surface. The numerous positive results obtained by PCR suggest that the parasite was widely present in the lagoon at the sampling dates. Some of these results might be explained by the feeding behaviour of the zooplankton species. For example, appendicularians are filter feeders which can thus capture parasites when filtering while chaetognaths are carnivorous, preying on other zooplanktonic organisms including copepods that can be infected with the parasite.

Molecular characterization efforts were done in order to identify $M$. refringens types circulating in Diana lagoon.

The phylogenetic analysis of the 12 obtained sequences confirmed the distribution of the tested clones in three groups corresponding to types M, $\mathrm{O}$ and $\mathrm{C}$. Genetic distance was low, below $1 \%$ within each of these groups of sequences. Type $\mathrm{C}$ appeared genetically more distant from other types: 7 and 11\% from types $\mathrm{M}$ and $\mathrm{O}$ respectively whereas overall distance between types $\mathrm{M}$ and $\mathrm{O}$ sequences was below $2 \%$. These results support the hypothesis that types $\mathrm{M}$ and $\mathrm{O}$ represent the same unique species, $M$. refringens. However, the relative position of type $\mathrm{C}$ would require further molecular work.

In the present study, $M$. refringens type $\mathrm{M}$ appeared predominant in mussels and zooplankton. However, it was possible to demonstrate that type $\mathrm{O}$ was also present and might circulate between zooplankton and mussels. In addition, Marteilia sp. close to Marteilia sp. type C was also detected in one sample of zooplankton collected in September 
suggesting that this Marteilia type is also circulating in the lagoon. Cerastoderma edule has never been reported whereas several cockle species including Acanthocardia paucicostata, Anadara inaequivalvis and Parvicardium exiguum are present at low density in Diana lagoon (Casabianca et al. 1973; Andral and Sargian, 2010). The detection of Marteilia sp. type C in zooplankton raises some questions concerning the status of these different cockle species regarding the parasite.

Although $M$. refringens types $\mathrm{O}$ and $\mathrm{M}$ are preferentially detected in flat oysters and mussels respectively, host affinity is not strict (Le Roux et al. 2001; Lopez-Flores et al. 2004; Novoa et al. 2005; Carrasco et al. 2008b). Carrasco et al. (2008b) hypothesized that when parasitic loads are high in the environment, a predominant type could infect both flat oysters and mussels. In our study, flat oysters appeared free of $M$. refringens although both types were detected in mussels and also in zooplankton.

\section{CONCLUSIONS}

To conclude, our results show that $M$. refringens is able to accomplish its life cycle in Diana lagoon in Corsica through mussels $M$. galloprovincialis. The decrease of detection frequency in mussels coincides with the detection of parasite DNA in zooplankton samples which suggests that $M$. refringens is transmitted from mussels to zooplankton. Multiple taxa of zooplankton yielded positive results by PCR whereas only one species showed positive and specific labelling by ISH. The parasite was probably abundant in the water but did not truly infect these taxa. Another interesting point is that P. grani was not identified in zooplankton samples tested in the present study. Moreover, the parasite was detected in gonadal tissue of $P$. latisetosa collected in September 2007. Therefore, depending on its ecological context, the parasite seems to target different species of the Paracartia genus to accomplish its life cycle. Both Paracartia species seem not able to co-occur as $P$. grani is present in claire ponds and in Thau lagoon (Audemard et al. 2001; Boyer et al. 2012) and P. latisetosa in Diana lagoon and in Thau lagoon before the arrival of $P$. grani in the lagoon (Boyer et al. 2012). Ecology and interactions between both species are therefore to be studied to better understand the role of zooplankton species in the Marteilia life cycle. Marteilia refringens type $\mathrm{M}$ appeared predominant in the lagoon during the studied period but was not unique. Indeed, other types including type $\mathrm{O}$ and Marteilia sp. type $\mathrm{C}$ were also detected in mussels or zooplankton samples. These results raise some questions regarding the environmental conditions favouring one or another type.

\section{ACKNOWLEDGEMENTS}

The authors would like to thank Mr B. Pantalacci, shellfish farmer in Diana lagoon, Corsica. We gratefully acknowledge Jean-Philippe Herbourg, Yann Couraleau and Sophie Lerond for their great technical contribution to this study. We also thank Corinne Tomasino for the map of Diana lagoon in Fig. 1.

\section{FINANCIAL SUPPORT}

The present study was supported by the REMCO project through a grant allocated by the Territorial Collectivity of Corsica and the Regional delegation for research and technology of Corsica.

\section{REFERENCES}

Alderman, D. J. (1979). Epizootiology of Marteilia refringens in Europe. Marine Fisheries Review 41, 67-69.

Altschul, S. F., Madden, T. L., Schaffer, A.A., Zhang, J., Zhang, Z., Miller, W. and Lipman, D. J. (1997). Gapped BLAST and PSI-BLAST: a new generation of protein data base search programs. Nucleic Acids Research 25, 3389-3402.

Andral, B. and Sargian, P. (2010). Directive Cadre Eau - District "Corse" Contrôles de surveillance/opérationnel (campagne DCE 2009) RST. DOPLER/PAC/10-20, décembre 2010.

Audemard, C., Barnaud, A., Collins, C. M., Le Roux, F., Sauriau, P. G., Coustau, C., Blachier, P. and Berthe, F. C. J. (2001). Claire ponds as an experimental model for Marteilia refringens life-cycle studies: new perspectives. Fournal of Experimental Marine Biology and Ecology 257, 87-108.

Audemard, C., Le Roux, F., Barnaud, A., Collins, C., Sautour, B. Sauriau, P. G., De Montaudouin, X., Coustau, C., Combes, C. and Berthe, F. (2002). Needle in a haystack: involvement of the copepoda Paracartia grani in the life-cycle of the oyster pathogen Marteilia refringens. Parasitology 124, 315-323.

Balouet, G., Chaste, C., Cahour, A., Quillard, A. and Poder, M. (1979). Etude épidémiologique et pathologique de la maladie de l'huître plate en Bretagne. Bulletin de l'Institut des Pêches Maritimes 289, 13-23.

Balseiro, P., Montes, A., Ceschia, G., Gestal, C., Novoa, B. and Figueras, A. (2007). Molecular epizootiology of the European Marteilia spp., infecting mussels (Mytilus galloprovincialis and M. edulis) and oysters (Ostrea edulis): an update. Bulletin of the European Association of Fish Pathologists 27, 148-156.

Berthe, F. C. J., Pernas, M., Zerabib, M., Haffner, P., Thebault, A. and

Figueras, A. J. (1998). Experimental transmission of Marteilia refringens with special consideration of its life cycle. Diseases of Aquatic Organisms 34, 135-144.

Berthe, F. C. J., Le Roux, F., Peyretaillade, E., Peyret, P., Rodriguez, D., Gouy, M. and Vivares, C.P. (2000). The existence of the phylum Paramyxea Desportes and Perkins, 1990 is validated by the phylogenetic analysis of the Marteilia refringens small subunit ribosomal RNA. Fournal of Eukaryotic Microbiology 47, 288-293.

Boyer, S., Arzul, I. and Bonnet, D. (2012). Some like it hot: Paracartia grani (Copepoda: Calanoida) arrival in the Thau lagoon (south of FranceMediterranean Sea). Marine Biodiversity Records. doi: 10.1017/ S1755267212000565.

Burreson, E. M. (2008). Misuse of PCR assay for diagnosis of mollusc protistan infections. Diseases of Aquatic Organisms 80, 81-83. doi: 10.3354/ dao01925.

Carrasco, N., López-Flores, I., Alcaraz, M., Furones, M.D., Berthe, F. C. J. and Arzul, I. (2007a). Dynamics of the parasite Marteilia refringens (Paramyxea) in Mytilus galloprovincialis and zooplankton populations in Alfacs Bay (Catalonia, Spain). Parasitology 134, 1541-1550. doi: 10.1017/S0031182007003009.

Carrasco, N., López-Flores, I., Alcaraz, M., Furones, M.D., Berthe, F. C. J. and Arzul, I. (2007b). First record of a Marteilia parasite (Paramyxea) in zooplankton populations from a natural estuarine environment. Aquaculture 269, 63-70.

Carrasco, N., Arzul, I., Chollet, B., Robert, M., Joly, J.-P., Furones, D. and Berthe, F.C.J. (2008a). Comparative experimental infection of the copepod Paracartia grani with Marteilia refringens and Marteilia maurini. Fournal of Fish Diseases 31, 497-504. doi: 10.1111/j.13652761.2008.00910.x. 
Carrasco, N., Arzul, I., Berthe, F.C. J., Fernàndez-Tejedor, M., Dufort, M. and Furones, M. D. (2008b). Delta de l'Ebre is a natural bay model for Marteilia spp. (Paramyxea) dynamics and life-cycle studies. Diseases of Aquatic Organisms 79, 65-73. doi: 10.3354/dao01844.

Carrasco, N., Andree, K. B., Lacuesta, B., Roque, A., Rodgers, C. and Furones, M. D. (2012). Molecular characterization of the Marteilia parasite infecting the common edible cockle Cerastoderma edule in the Spanish Mediterranean coast. A new Marteilia species affecting bivalves in Europe. Aquaculture 324-325, 20-26. doi: 10.1016/j.aquaculture.2011.10.017. Casabianca, M.L., Kiener, A. and Huvé, H. (1973). Biotopes et biocénoses des étangs saumâtres corses: Biguglia, Diana, Urbino, Palo. Vie et Milieu, 23(2-C), 187-227.

Comps, M. (1970). Observations sur les causes d'une mortalité anormale des huîtres plates dans le bassin de Marennes. Revue des Travaux de l'Institut des Pêches Maritimes 34, 317-326.

Comps, M., Grizel, H. and Papayanni, Y. (1982). Infection parasitaire causée par Marteilia maurini sp. n chez la moule Mytilus galloprovincialis. CIEM C.M. 1982/F:24:3 pp

Comps, M., Park, M. S. and Desportes, I. (1986). Ultrastructural study of Marteilioides chungmuensis gen. nov., sp. nov., a parasite of the ovocytes of the oyster Crassostrea gigas Th. Protistologica 22, 279-285.

Figueras, A. J. and Robledo, J. A. F. (1993). Does the Marteilia present in mussels (Mytilus galloprovincialis) infect flat oyster (Ostrea edulis)? Bulletin of the European Association of Fish Pathologists 13, 97-99.

Ginsburger-Voge1, T. and Desportes, I. (1979). Etude ultrastructurale de la sporulation de Paramarteilia orchestiae gen. N. sp.n. parasite de l'amphipode Orchestia gammarellus. Marine Fishery Review 41, 3-7.

Goulletquer, P. and Héral, M. (1997). Marine molluscan production trends in France: from fisheries to aquaculture. NOAA Technical Report NMFS series $129,137-164$

Grizel, H. (1985). Etudes des récentes épizooties de l'huitre plate Ostrea edulis L. et de leur impact sur l'ostréiculture bretonne. Ph.D. dissertation. Université des Sciences et Techniques de Languedoc, Montpellier, France. Grizel, H. and Tigé, G. (1973) La maladie de la glande digestive d'Ostrea edulis Linné. CIEM C.M.1973/K:13:7 pp.

Grizel, H., Comps, M., Cousseraris, F., Bonami, J. R. and Vago, C. (1974). Etude d'un parasite de la glande digestive observé au cours de l'épizootie actuelle de l'huître plate. Compte Rendu de l'Académie des Sciences Série D Paris 279, 783-784.

Howard, A. W. and Smith, C.S. (1983). Histological techniques for marine bivalve mollusks. NOAA Technical Memorandum NMFS-F/ NEC-25, Woods Hole.

Le Roux, F., Audemard, C., Barnaud, A. and Berthe, F. (1999). DNA probes as potential tools for the detection of Marteilia refringens. Marine Biotechnology 1, 588-597.

Le Roux, F., Lorenzo, G., Peyret, P., Audemard, C., Figueras, A., Vivares, C., Gouy, M. and Berthe, F. (2001). Molecular evidence for the existence of two species of Marteilia in Europe. Fournal of Eukaryotic Microbiology 48, 449-454.

Longshaw, M., Feist, S. W., Matthews, A. and Figueras, A. (2001). Ultrastructural characterisation of Marteilia species (Paramyxea) from Ostrea edulis, Mytilus edulis and Mytilus galloprovincialis in Europe. Diseases of Aquatic Organisms 44, 137-142.

Lopez-Flores, I., de la Herran, R., Garrido-Ramos, M. A., Navas, J. I., Ruiz-Rejon, C. and Ruiz Rejon, M. (2004). The molecular diagnosis of
Marteilia refringens and differentiation between Marteilia strains infecting oysters and mussels based on the rDNA IGS sequence. Parasitology 12 , 411-419. doi: 10.1017/S0031182004005827.

Meuriot, E. and Grizel, H. (1984). Note sur l'impact economique des maladies de l'huître plate en Bretagne. Rapport Technique I.S.T.P.M. 12:19 pp

Novoa, B., Posada, D. and Figueras, A. (2005). Polymorphisms in the sequences of Marteilia internal transcribed spacer region of the ribosomal RNA genes (ITS-1) in Spain: genetic types are not related with bivalve hosts. Fournal of Fish Diseases 2, 331-338. doi: 10.1111/j.13652761.2005.00634.x.

OIE, Office International des Epizooties (2011). Aquatic Animal Health Code, 79th Edn. OIE, Paris.

OSPAR agreement 2008-6. Ospar convention for the protection of the marine environment of the northeast Atlantic. www.ospar.org/ html_documents/ospar/html/ospar_list_of_decsrecs.pdf.

Pichot, Y. (2002). Bilan de l'état zoosanitaire des mollusques en méditerranée française 1988-2001. DRV/RST/RA/LCM/2002-11, 36 pp. R Core Development Team (2009). $R$ : a language and environment for statistical computing version 2.12.1. http://www.r-project.org.

REPAMO (2005). Bilan 2004 du réseau REPAMO (Réseau national de surveillance zoosanitaire des mollusques marins). $69 \mathrm{pp}$.

REPAMO (2007). Bilan 2006 du réseau REPAMO (Réseau national de surveillance zoosanitaire des mollusques marins). $38 \mathrm{pp}$.

Robledo, J. A. F. and Figueras, A. J. (1995). The effects of culture-site, depth, season and stock source on the prevalence of Marteilia refringens in cultured mussels (Mytilus galloprovincialis Lmk.) from Galicia. Spain. Fournal of Parasitology 81, 354-363.

Saitou, N. and Nei, M. (1987). The neighbor-joining method: a new method for reconstructing phylogenetic trees. Molecular Biology and Evolution 4, 406-425.

Tajima, F. and Nei, M. (1984). Estimation of evolutionary distance between nucleotide sequences. Molecular Biology and Evolution 1, 269-285.

Tamura, K., Peterson, D., Peterson, N., Stecher, G., Nei, M. and Kumar, S. (2011). MEGA5: molecular evolutionary genetics analysis using maximum likelihood, evolutionary distance and maximum parsimony methods. Molecular Biology and Evolution 28, 2731-2739. doi: 10.1093/ molbev/msr121

Thompson, J. D., Higgins, D. G. and Gibson, T. J. (1994). CLUSTAL $\mathrm{W}$ : improving the sensitivity of progressive multiple sequence alignment through sequence weighting, position specific gap penalties and weight matrix choice. Nucleic Acid Research 22, 4673-4680.

Villalba, A., Mourelle, S. G., López, M. C., Carballal, M. J. and Azevedo, C. (1993). Marteiliasis affecting cultured mussels Mytilus galloprovincialis of Galicia (NW Spain). Etiology, phases of the infection, and temporal and spatial variability in prevalence. Diseases of Aquatic Organisms 16, 61-72.

Virvilis, C., Angelidis, P. and Photis, G. (2003). Presence of the parasite Marteilia sp. in the shellfish of the Thermaikos gulf in northern Greece. Bulletin of the European Association of Fish Pathologists 23, 157-162.

Zrncic, S., Le Roux, F., Oraic, D., Sostaric, B. and Berthe, F. C. J. (2001). First record of Marteilia sp in mussels Mytilus galloprovincialis in Croatia. Diseases of Aquatic Organisms 44, 143-148. 